\title{
MINIMNYA KEINGINAN BELAJAR DIPENGARUHI OLEH MASALAH EKONOMI
}

\author{
Nur Azizah \\ Email : 2010128220004@mhs.ulm.ac.id \\ Program Studi Pendidikan IPS Fakultas Keguruan dan Ilmu Pendidikan \\ Universitas Lambung Mangkurat \\ Banjarmasin
}

\begin{abstract}
Abstrak
Pengaruh ekonomi terhadap suatu pendidikan sangatlah besar. Yang mana pada dasarnya pendidikan merupakan harapan yang dapat menunjang suatu proses pengembangan sebuah kehidupan berekonomi, karena pada dasarnya pelaku dari dari kehidupan ekonomi tersebut ialah manusia itu sendiri. Lalu perkembangan sebuah ekonomi juga dapat menunjang terjadinya suatu proses pendidikan yang mana proses tersebut dibutuhkan dalam perkembangan ekonomi. Kehilangan pekerjaan yang merupakan penghasilan untuk biaya hidup sehari-hari dapat menimbulkan kehilangan pendapatan serta menyebabkan ketidakstabilan dalam situasi pada ekonomi hal ini memicu terjadinya kemiskinan. Dalam konteks ini pendidikan tidak hanya bermanfaat untuk perorangan saja dalam suatu rangka meningkatkan ilmu pengetahuan, akan tetapi sebagai sebagai sebuah komunitas dalam menuju kemajuan untuk pencapaian suatu kesejahteraan sosial dan dapat menjadikan perekonomian dinegara menjadi stabil, sedangkan apabila terjadi kegagalan adalam suatu pendidikan akan menciptakan berbagai macam masalah. Dari sini kita dapat berkaca atau berpandangan pada negara yang maju, karena negara yang maju lebih mengutamakan pendidikan untuk menghasilkan sumber daya manusia yang maju serta berkualitas.
\end{abstract}

\section{PENDAHULUAN}

Masalah pendidikan sebernarnya tidak terlepas dari masalah ekonomi baik itu secara langsung maupun tidak langsung, kontribusi suatu pendidikan dalam ekonomi di pembangunan harus diakui adanya. Dengan begitu pendidikan tidak selamanya dianggap sebagai suatu konsumsi atau pembiayaan. Yang mana seharusnya pendidikan dijadiakan sebagai investasi dengan konstribusi dengan jangka panjang dapat kita rasakan. Dalam konteks ini konsep pendidikan sebagai investasi berkembang secara cepat dan telah diyakini oleh setiap oran di negara yang mana sektor pembangunan pendidikan menjadi prasyarat untuk pembangunan 
sektor yang lainnya. Dimana pendidikan menjadi sebuah leading sectro di perkembangan suatu ekonomi dan modernisasi sebuah bangsa, dengan begitu sangat diperlukan langkah yang sistematis dalam pencapaian tujuan suatu pendidikan. Yang mana tujuan tersebut berupaya mencerdaskan kehidupan bangsa dan menjadikan negara ini menjadi negara yang dipatuhi oleh negara lain. Dalam hal ini pula menjadikan pendidikan sebagai faktor penting dalam menentukan tingkat upah terhadap seseorang sehingga dapat memberikan suatu konstribusi yang cukup besar kepada distribusi pendapatan suatu masyarakat. Sudah menjadi hal yang wajar bahwa bekerja merupakan suatu uapaya untuk mendapatkan sebuah penghasilan atau pendapatan dari sebagian besar orang dalam msayarakat tersebut. Yang mana status pekerjaan dijadikan sebagai sumber utama dalam penentu upah atau tingkat gaji. Disini banyak yang condong kepada pendidikan sebagai suatu faktor penting dalam mendapatkan suatu pekerjaan atau status pekerjaan yang layak. Dalam hal ini pula semakin maraknya pendidikan yang digapai oleh anak didik atau seseorang yang ingin belajar dengan begitu akan semakin tinggi pula status pekerjaan atau pendapatan yang akan mereka dapatkan dan mereka miliki.

\section{PERMASALAHAN PENDIDIKAN DIKARENAKAN BIAYA EKONOMI}

Mengingat pada biaya pendidikan yang terus menerus meningkat pada setiap tahunnya, menyebakan sebagian orang dalam rakyat kecil penghasilannya atau rakyat miskin semakin rendah pula pendidikan yang mereka dapatkan, lain halnya denga rakyat kalangan atas atau orang-orang kaya yang justru mendapatkan pendidikan dengan fasilitas yang nyaman serta bagus. Dengan begini menyebabkan kualitas dalam pendidikan tidak seimbang dikarenakan suatu ekonomi. Hal ini menjadikan terjadinya ketimpangan dalam pendapatan. Dalam distribusi pendapatan perlu adanya pengukuran terhadap suatu kemiskinan yang relatif sangat banyak. Dalam hal ini terdapat dua kategori tingkat kemiskinan yaitu ada kemiskinan absolut serta kemiskinan relatif. Kemiskinan absolut merupakan kemiskinan yang tidak dapat memenuhi biaya kebutuhannya seperti halnya pangan, sandang, pendidikan serta kesehatan, yang mana kemiskinan absolut ini tidak dapat memenuhi kebutuhan hidupnya sama sekali atau pendapatannya tidak memadai untuk kebutuhan hidupnya. Sedangkan kemiskinan relatif ialah kemiskinan yang berdasarkan suatu perhitungan proporsi suatu pendapatan dari sebuah daetah maupun wilayah.

Maraknya anak putus sekolah dikarenakan oleh bermacam faktor yakni salah satunya faktor ekonomi. Faktor ekonomi yang membuat mereka putus sekolah dan menjadikan anak minim untuk berkeinganan belajar dikarenakan pekerjaan orang tua mereka yang tidak mampu 
membiayai mereka untuk bersekolah atau mendapatkan sekolah yang bagus, hal ini juga dipengaruhi dengan tanggungan keluarga yang banyak sehingga memicu mereka untuk memutuskan berhenti sekolah, dan yang pastinya tingkatan pendapatan yang tidak memadai mereka untuk bersekolah. Selain itu juga ada yang disebakan oleh kegiatan produktif did alam rumah tangga. Dan akhirnya membuat anak menjadi malas dan menganggap pendidikan itu tidak terlalu penting. Hal ini juga dikarenakan kurangnya dukungan serta motivasi dari orang tua terhadap anaknya tentang pentingnya pendidikan itu. Pada era globalisasi saat ini pendidikan sangatlah penting untuk kemajuan anak bangsa. Karena semakin rendahnya tingkat pendidikan maka akan semakin rendah pula sumber manusia yang berkualitas dan hal ini pastinya akan berpengaruh kepada potensi terhadap bangsa serta negara karena minimnya tingkat sumber daya manusia yang cerdas. Sementara itu pendidikan juga merupakan usaha manusia dalam membangun manusia tersebut dalam segala masalah atau problem yang mana tidak terlepas dari spektrum dimensi ruang dan waktu. Macam-macam pendidikan berupa pendidikan formal, nonformal dan sebagainya. Pendidikan juga memicu akan meningkatnya suatu martabat seseorang untuk agar memiliki suatu keterampilan dan kemampuan agar produktivitasnya juga meningkat. Oleh karena itu pendidikan adalah suatu upaya dalam menjadikan sumber daya manusia yang sangat bermanfaat bagi negara.

Ekonomi dalam pendidikan dikenal cukup sebagai yang menentukan bukan sebagai pemegang peranan yang penting. Oleh karena itu perlu adanya dedikasi, keterampilan, keahlian serta bakat dari guru-gurunya hal ini memicunya keberhasilan dalam pembelajaran dengan adanaya dedikasi yang bagus, keterampilan dalam melakukan pembelajaran dengan keahlian dalam penyampaian pembelajaran. Fungsi ekonomi bagi suatu pendidikan merupakan penunjang kelancaran bagi proses pendidikan yang mana peran ekonomi dalam sekolah menjadi salah satu bagian dari sumber pendidikan yang menjadikan anak didik bisa mengembangkan pengetahuan, keterampilan, agar anak didik dapat menjadi tenaga kerja yang berkualitas juga handal dan memadai sehingga dapat menciptakan serta membentuk lapangan kerja sendiri, dengan di bekali oleh etos kerja yang bagus, hal ini juga menjadikan anak didik hidup secara hemat. Bukan hanya itu dalam menunjang proses pendidiakan dalam ekonomi, hal ini juga berfungsi di masalah ekonomi dalam kehidupan manusia. Pertumbuhan ekonomi juga dipengaruhi oleh berbagai fakto yaitu tenaga kerja, modal, dan kemajuan sebuah teknologi.

\section{MOTIVASI BELAJAR UNTUK PESERTA DIDIK}


Pendidikan meruapakan suatu upaya sebuah usaha untuk manusia dalam membina kepribadian manusia tersebut sesuai dengan norma yang ada. Peranan pendidikan dalam semua aspek kehidupan manusia sangatlah penting, pada saranya pendidikan merupakan suatu bentuk dalam lingkungan dalam melakukan suatu perubahan dalam sikap individu yang mendapatkannya. Sebagaimana semestinya sekolah memeliki peranan penting untuk mendidik dan memberikan ilmu pengetahuan serta pembelajaran serta membimbing peserta didik dalam pencapaian sebuah tahap-tahap yang optimal untuk membuahkan hasil dari afektif, psikomotorik dan kognitif mereka dengan maksimal. Motivasi belajar memebrikan suatu fungsi atau energi penggerak terhadap tingkah laku anak didik, menentukan arahan perbuatan kepada anak didik, dan menentukan sebuah intensitas anak didik dalam perbuatan. Motivasi juga mendorong seseorang untuk menjadi lebih maju dan ingin tau dalam usaha yang sudah ia raih, motivasi disini juga sebagai suatu konsep yang menggambarkan perilaku seseorang yang baik. Anak yang mendapatkan suatu motivasi dan dorangan memiliki kinerja yang baik dalam menangkap pembelajaran daripada anak yang tidak termotivasi, hal ini dikarenakan kurangnya kepekaan terhadap orang tua atau orang sekitar yang memotivasinya sehingga ia lebih cenderung malas dan bosan dalam pembelajaran. Belajar tanpa adanya motivasi biasanya akan sulit untuk medapatkan pembelajaran yang optimal (Oemar Hamalik,2005:108). Motivasi juga dapat membantu peserta didik yang malas atau bosan dalam mengikuti pembelajaran dapat membantu mereka yang sedang bosan atau malas untuk menjadi semangat lagoi dalam pembelajaran karena disana meraka merasa mendapat dorongan untuk belajar lebih giat lagi. Rendahnya motivasi dalam belajar disebabkan oleh berbagai macam hambatan-hambatan tertentu dalam upaya pencapaian hasil belajar yang bagus, dan dipengaruhi pula oleh berbagai aspek yakni psikologis, sosiologi dan fisiologis sehingga hal ini memicu terjadinya prestasi belajar berada di bawah rata-rata. Rendahnya motivasi belajar juga di pengaruhi oleh diri sendiri dan juga dari luar diri anak didik tersebut.

\section{KESIMPULAN}

Dengan begitu mengapa minimnya semangat belajar anak dalam pendidikan dikarenakan berbagai macam faktor salah satunya faktor ekonomi, mengapa faktor ekonomi disebut sebagai pemicu minimnya keinginan anak dalam menuntut ilmu ialah karena kebanyakan anaka dari kalangan miskin tidak dapat bersekolah dengan baik seperti teman-temannya yang mampu bersekolah, sebagian sekolah yang bagus atau sekolah yang familiar biasanya kebanyakan mengguankan biaya yang cukup mahal sehingga anak yang ingin bersekolah disana pun harus dari kalangan anak orang kaya, hal yang menjadi penyebab minimnya keinginan anak belajar 
juga dipengaruhi oleh tanggungan keluarga yang banyak sehingga membuat mereka berpikir dua kali untuk bersekolah. Dengan begini banyak anak yang beranggapan bersekolah itu tidak harus dilakukan dan kebanyakan dari mereka lebih memilih bekerja bahkan menjadi pengemis sekalipun dikarenaka ekonomi yang tidak stabil. Upaya untuk anak agar tetap ingin belajar yaitu dengan adanya motivasi atau dorongan baik itu dari orang tua, sekolah, lingkungan dan teman sebayanya. 


\section{DAFTAR PUSTAKA.}

Anis, M. Z. A., Putro, H. P. N., Susanto, H., \& Hastuti, K. P. (2020). Historical Thinking Model in Achieving Cognitive Dimension of Indonesian History Learning. PalArch's Journal of Archaeology of Egypt/Egyptology, 17(7), 7894-7906.

Widiansyah, A. (2017). Peran ekonomi dalam pendidikan dan pendidikan dalam pembangunan ekonomi. Cakrawala-Jurnal Humaniora, 17(2), 207-215.

Nadya, A., \& Syafri, S. (2019). Analisis Pengaruh Faktor Pertumbuhan Ekonomi, Pendidikan, dan Pengangguran terhadap Ketimpangan Distribusi Pendapatan di Indonesia. Media Ekonomi, 27(1), 37-52.

Ulfani, D. H., Martianto, D., \& Baliwati, Y. F. (2011). Faktor-faktor sosial ekonomi dan kesehatan masyarakat kaitannya dengan masalah gizi underweight, stunted, dan wasted di Indonesia: Pendekatan ekologi gizi. Jurnal gizi dan pangan, 6(1), 59-65.

Lisnawati, C. (2007). Aspek ekonomi dalam pendidikan. Educare.

Nugroho, S. B. M. (2016). Pengaruh Pendidikan Terhadap Pertumbuhan Ekonomi. Media Ekonomi dan Manajemen, 29(2).

Syaharuddin, S., ABBAS, E. W., Subiyakto, B., Winarso, H. F., Permatasari, M. A., Olfah, R., \& Rusli, R. (2018). Motivasi Belajar Anak Jalanan (Studi Kasus pada Anak Jalanan yang Bersekolah di SD Mawar 2 Banjarmasin). Motivasi Belajar Anak Jalanan (Studi Kasus pada Anak Jalanan yang Bersekolah di SD Mawar 2 Banjarmasin).

Putro, H. P. N., \& Alviawati, E. (2021). PENGEMBANGAN MODEL PEMBELAJARAN ILMU PENGETAHUAN SOSIAL (IPS) UNTUK PENGURANGAN RESIKO BENCANA DI SEKOLAH PADA DAERAH RAWAN BENCANA DI LINGKUNGAN LAHAN BASAH KABUPATEN BANJAR. In PROSIDING SEMINAR NASIONAL LINGKUNGAN LAHAN $B A S A H$ (Vol. 6, No. 1). 